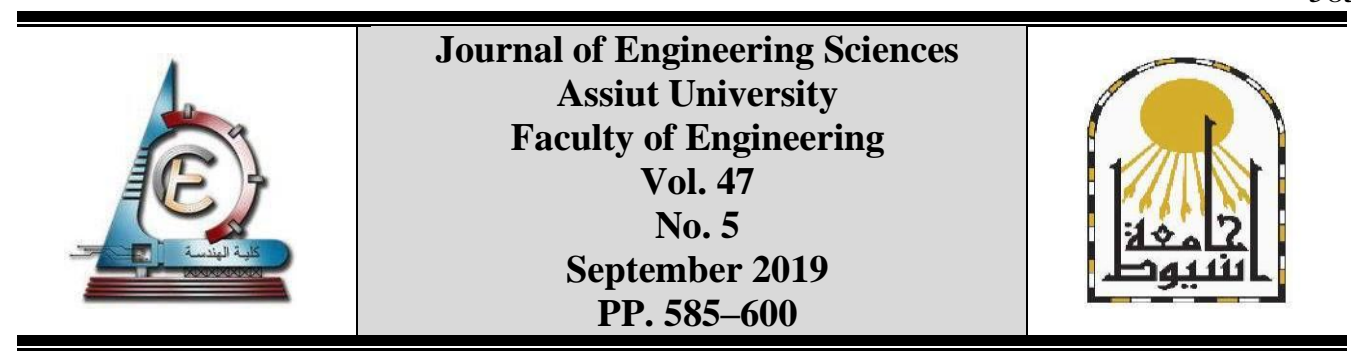

\title{
URBAN VOIDS AS POTENTIOAL RESOURCES FOR THE CITY DEVELOPMENT
}

\author{
Nermeen Ali Omar, Engy Hassan Saeed \\ Architecture engineering department, engineering Faculty, Tanta University
}

Received 28 February 2019; Accepted 27 April 2019

\begin{abstract}
ABESTRACT
Recently, many cities suffer from urban development problems due to rapid urbanization, population growth and economic crisis which affect quality of life in the city. On the other hand there are many urban voids in these cities that formed because of many natural, historical, and economic factors. These unused urban voids introduce complicated negative impacts on the communities and the urban fabric that it exists in. Despite of the negative effect of the urban voids on the city, it provides great opportunities for urban development and considered as potential resources for redevelopment the city. It can achieve by utilizing the urban voids by programs of reuse that integrated with the development objectives of the city. The research aims to understand the meaning of urban voids and its formations and highlight the importance of the urban voids as potential resources for development the city. The research also determines the urban voids values which are identified as; environmental value, social value, economic value, historical cultural value and aesthetic value. Also, through the theoretical study and the lessons learned from analysis international examples, the research develops a framework to help planners and designers to improve the ways of re-using urban voids to maximize their utilization. The research concludes that the urban voids should be well managed to maximize its effectiveness and decrease any negative effect. In addition, effective re-use of urban voids requires integrate these voids as a part of the urban fabric and cooperation between all stakeholders who involved in the development process.
\end{abstract}

Keywords: urban voids - vacant land - potential resource- utilization- urban voids values.

\section{Introduction}

Rapid urbanization and population growth are major challenges facing cities in our modern time. [16] Dealing with these problems has become major political, economic and social pressures on the cities which suffer from many problems that affect the quality of life such as lack of resources, limited open spaces and public spaces, environmental problems and ignore of human dimension in development processes. With all of these problems and challenges, it is necessary to search for resources to alleviate or reduce these problems. Urban voids are one of the most important vital resources and a useful component of significant benefits that represent great opportunities for development the city. So, it should be managed to maximize its effectiveness and decrease any negative effects. it is necessary to form government strategies and programs to deal with these spaces by invest and utilize them in development process. 
In this study, an overview of international literature and theories and examples from different cities are used to illustrate the role of un-used urban voids spaces as a powerful tool and potential resource for the urban development. [21] The study have pointed out the important benefits and values which are related to re-use urban voids which include environmental, social, historical, economic and visual benefits, leading to consider re-use and redevelop urban voids as a catalyst and potential resources for future urban development of the city.

\section{1 problem definition}

At the last decade since the beginning of $21^{\text {th }}$ century, the problem of urban voids and underutilized spaces has become an important problem especially in rapidly urbanization cities due to its negative impact on the city. Urban voids development has become more common and the important of re-use and transformation of these voids is increasing. [1-6] In 1950s and 1960s, urban void spaces were emerged the old city centers which include many industrial and commercial functions which moved out to suburbs and left behind unused gapes and abandoned buildings, [6] with very important location inside the city. [1] In 1970s especially in EU and US, the interest of reclaiming and re-use urban voids and abandoned buildings increased. [5] Some movements have emerged from squatters to take advantage of these unused neglected spaces. From 1980s, the public private cooperation and new programs were formed so as to re-use the industrial areas to transform it into offices and resident spaces. [13] In the following decade, the processes of regeneration and re-habitation have been deal with urban voids and unused spaces, and there have been strategies to go back to city center which related to this processes.

Urban voids introduce complicated negative impacts on the communities and urban fabric that it exist in. [9] these impacts can be classified in to Social problems such as providing suitable places for criminal activities which have become threatening public security. Also, urban voids can be rubbish dumps, trash filled yards. It provides places for informal uses like places for homeless people and illegal housing. [23] Economic problems in order to unused urban voids and abandoned buildings decay surrounding areas and prevent investment and development. Also, the negative impacts of urban voids contribute to a certain decline in properties values. [12]. Environmental problems like visual pollution and health risks which are result of these waste filled yards, And urban problems result from unattractive voids which impact negatively on the city appearance and the urban quality of the city. [12-26] because of the openness and expansion of some urban voids the cohesion of the city urban fabric is affected. [12-26]

This paper is concerned with identify and understand the problem of urban voids which is considered a challenge and potential for developers at the same time.[1] and attempt to represent urban voids as an important resource of the process of urban development by determine the values and benefits that these spaces can offer.

\subsection{Objectives}

The purpose of this paper is to understand the meaning of urban voids and its formations, and highlight the importance of the urban voids as potential resources to explore its environmental, social, economic, cultural and aesthetic values. Also, through the theoretical study and the analysis of the lesson learned from analysis international examples, the study develop a framework for re-use the urban voids to help planners and designers to improve the ways of reusing urban voids to maximize their utilization. 


\section{Methodology}

The research based on two approaches. Firstly, the theoretical approach which reviews the literature relevant to urban voids to understand clear theoretical definition of such areas and the reasons for their formation and its impact on the city. Also, determine the values and benefits to re-use urban voids for the development of the city, and to improve the quality of life. The second approach is the analytical approach which presents a set of international examples for the projects of reuse of urban voids and analysis of these examples to take advantages and disadvantages. From the theoretical study and the analysis of the lesson learned from international examples the research develop a framework for improve the way of development and reuse of urban voids to maximize their benefits.

\section{Urban voids definition}

The term of urban void can be defined in many different ways. The definitions are related to the way they were generated, their origins [21], the history of their existence, and the possibility of transformation. So, the description of urban voids would include its spatial aspects and also the time. [21] Though the review of the literature, there seems to be confusion between the terms urban voids, vacant spaces, terrain vague, abandoned, derelict land...etc.

The research focuses on the term urban voids which refer to the voids in term of urban concept of lacking functions, lacking people and lack of aesthetic values. [26] Also, the voids of the city are the spaces which perturb the urban tissue leaving it incomplete, there are without belonging or at the limit between public and private. These also mean the vacancies of spaces then become left-over and negative spaces in urban fabric.

Many urban theories pointed out the importance of the lost urban spaces which are undefined spaces in the city. According to (trancik 1986) lost spaces or undefined spaces existed in every modern city with big amount due to the ill master plan and planning approaches which produced undefined spaces that turn in to unused spaces [25], $\mathrm{He}$ defined these spaces as negative, lost, and have low human activity. This is often the case along railroads line, unformed hidden land, along highway, old military yard, and disused industrial sites....etc. [25] According to (lynch 1981) waste spaces are described as neglected, unused, dead spaces. These spaces are created because of fixed functions spaces which leftover spaces usually are located next to the spaces with fixed function such as (highway, railway, under bridges...etc.). He argues that these spaces have potential for reuse and relief by increasing flexibility of spaces to appropriate all time's need. $\mathrm{He}$ discussed two types of lost spaces; spaces for unknown function such as leftover undefined spaces and the other type is spaces for specific uses. [17] According to (cerleau 1988) wastes spaces are formed due to the administration distribute different parts of the city and reject any spaces that were not deal with it. These spaces have become forgotten and blind spots in the city. He argued that these waste spaces have potentials in weaving the city together and the have important role to manage utilizing those undefined spaces. [4]

The urban voids have different types such as naturals they are located around metropolitan areas, interiors which located in already built cities, caught between that appear in between the compact city and the new urban development and interstitial which have a liner shape and located close to natural element or close to infrastructure such as (motor ways, rail ways....etc.). 


\section{Urban voids formation factors}

There are many factors affecting the formation of urban voids such as:

Natural factors: geographical factors affect the formation of urban voids; it can be physical obstacles in land form which create unshaped, undefined spaces that unable to be useful. It also can be natural disasters that led to abandonment of people to some areas and turned to abandoned spaces or buildings without any use. [28]

Function factors: urban voids products because of the function of the land or its surrounding. It products of post-industrialism include closed industrial sites, it also the empty voids which are created under bridges, spaces at the edges of highway and unused train yards.

Political factors: wars and its negative change effect in the urban fabric of the city which led to formation of abandoned areas and vacant spaces. Another political factor is inefficient decision making and poor land management and efficient co-ordination between decision makers and stakeholders.

Economic factors: urban voids are result of the interlink ages between economic shift and urban changes. The property value in the neighborhoods decline and its value decrease. The rental properties don't give enough income for owner's to pay taxes or maintain their properties and cover their costs which lead to the abandonment of owners of these properties that are no longer profitable. Also, financial disinvestment and higher taxes rate effect negatively of the urban core, big business and commercial activities leave the area with insufficient economic activities remain leading to abandonment of urban property. [12]

Planning and design factors: the modern movement in design approaches not suitable to the planning of many cities. This is the reason of creating separate buildings floating among parking lots and roads. [25] Urban voids also are the result of designing out of the context with the surrounding, regardless of urban fabric of the city.

Culture factors: the technological development and economic growth and people moving to live in the suburbs led to domination and wide spread use automobile. [25] This situation has decreased the use of city center which become an unpopular areas making it a suitable environment for the emergence of urban void spaces.

\section{Values of the urban voids}

Despite the negative impacts of urban voids on the city, it can be viewed as a vital and potential resource and provide a great values for the community to improve the quality of life. These values are environmental value, social value, economic value, culture value and visual value. The study will review these values and their impact on improving the city's life to be livable, healthy and sustainable. [Figure-1]

\subsection{Environmental value}

Urban voids can present many environmental benefits which led to enhance the quality of urban life. These unused spaces can be used as a green infrastructure and ecological resource to promote the ecosystem health. [15] Also, urban voids and underutilized spaces can support the biodiversity by reinforce preserving natural habitats for wide range of living organisms such as (plant, birds, insect, mammals...etc.) [13-15] 
In addition, urban voids can play a significant role in management the storm water. Recently, many cities in US as (Philadelphia, Cleveland, and Milwaukee) have established a storm water management strategy using urban voids as a part of it. [7] Also, vegetation and greening urban voids can improve the quality of air and reduce the pollution which positively affects the public health. These can also creating a green network of large or small open spaces that support climate change adaptation and play an important role in air cooling by reducing the urban heat island impact and can sequent reducing the use of air conditions and energy consumption. [11-23] in addition, urban voids can be used as a places to produce renewable energy (wind energy, solar energy...etc.) due to land can be rent to big power companies who will place their turbine or solar cells on these lands.

Example of the environmental benefits for urban voids seen in in European cities organization and statements made to emphasize the importance of unused spaces and vacant land in preserving the natural habitat (A British urban wild life habitat statement) confirm that urban voids contain the most diverse of London's habitat. [21]

Another example, the Detroit, MI in its greening program which its main goal is increase vegetation cover to maximize ecosystem services and improve the community through social considerations. So, about 1400 vacant lots greened and maintained and about 1400 vegetable gardens developed to achieve the program goals. [15]

From all of these examples it is clear that urban voids spaces can provide a possibility to offer many ecosystem functions which support sustainable urban regeneration process.

\subsection{Social value}

Urban voids represent a great potential to offer a range of social benefits and values to the community in the city urban voids can provides the opportunity to compensate for the shortage of open spaces that many cities suffer, especially cities with population density. The spaces play an important role to achieve social benefits that encourage people to act and reinforce social links, binding communities. Urban voids also can provide open spaces that accommodate a variety of uses and functions and social culture activities such as public open spaces, pocket gardens, community gardens, and public plaza. [20] These activities can increase the social interactions and sense of place. In addition, these voids can provide creative uses as social serveries such as entertainment activities, open restaurants, cafeterias, rickshaw auto stand, urban agriculture and education centers.[16] public spaces does not required high cost of complex design just comfort secure spaces for people gathering enabling them to enjoy and interact each other. [15] also, small urban voids which found randomly in urban fabric can offer the potential of forming network of connected spaces that have the ability to provide different level of inter actions and different types of uses. [24] In addition urban voids spaces offer locations for temporary uses such as seasonal celebrations, events, place for buy and sell, farmers market, as well as they can provide housing in the form of shelter for people who need shelter or to solve some housing problems resulting from lack of housing. [13]

One of the example which urban void turn to educational center the Gillespie park in UK that occupies 3.4 hectare as a local natural reserve which provides environmental education center for schools. The park holds community annual festival attended by 2000 persons each year. [15] Another example for social benefits the community gardens in New York City 1978 the operation (green thumb) was lunched. Urban voids spaces were 
contracted for community gardeners for 1 dollar per year. So, they are about 750 community garden rented with temporary contract. [22]

\subsection{Economic value}

Urban voids can provide the city with many economic benefits at several levels. These have a great potential to improve the economic activities of the city that can provide opportunities for investment and job creations. Also, these can offer working spaces at low cost and places for temporary uses which can become urban catalyst of the city development. [13] Reuse the urban voids as community gardens and agriculture land promoting urban agriculture and local food. [13] These voids also can provide small local business which support economic revitalization. These voids also provide good opportunities for local communities to increase its income through small-scale projects such as provide vending opportunities under the flyover through kiosks, booth and market. [16] Also, provides job opportunities and skills developments. In other level, urban voids affect the image of the city negatively leading to low investment in addition the local communities and public sectors bear the cost of maintenance these spaces. Therefore, the reuse or greening and vegetation of these spaces can improve the value of properties of surrounding areas and encourage investments. [1] In addition, regeneration and utilization of urban voids and abandoned buildings through projects that aim to emphasize its qualities can give a power of these places and increase its value in the market. [13]

For example of economic benefits the temporary use of urban voids in city of Craigavon (IE) for economic redevelopment. In the result of economic crisis, $25 \%$ of the Craigavon city abandoned and left vacant land and urban voids spaces in the city. All involved stakeholders set up program to temporary reuse of these buildings and spaces. As the result, the life brought back to the neighborhood, the appearance of the streets changed, increasing the safety at night and also increasing the business development.

\subsection{Historical and culture value}

Urban voids provide historical and cultural benefits to the city. At the level of historical benefits this spaces represent an integral part of the city and reflect its changes throughout history. [13] Urban voids and abandoned buildings have a strong link of the city's history, reusing these spaces considering its history enable supporting the historical memory, identity and character of the city.

For example the town of Catania- Italy implemented new program to improve the town's living conditions, this program aim to give back to Catania its unique identity. In May 1998 the university started a program in order to reuse an old degrading building located in the old area of Catania which was an abandoned factory, the goal of the program was turned the building in to library and language laboratory. The result of the project represents a good opportunity of development the town. [5]

On the other hand, on the level of cultural benefits these spaces are a great opportunity to support and develop cultural activities in the city. So, reuse urban voids as a culture spaces can create creative environment and bring character and uniqueness to the city. It can occur by create a temporary occupancy allow for arts uses and adapt existing buildings for new cultural uses. On the other hand, reusing the urban voids as green spaces can support the education process. Some studies have linked the benefit of green spaces with 
educational achievement. For example a study in Michigan has observed a positive relationship between the performance of high school student and nearby green spaces. [13]

\subsection{Visual and aesthetic values}

Urban voids viewed as an openings and blind spots in the urban structure which disrupt urban tissue leaving it incomplete. [28] The presence of these underutilized spaces affects negatively the visual image of the city and interconnectedness of the urban fabric. In addition it reduces the economic values of existing properties. The reuse and re-imagine the urban voids in creative attractive ways can solve the perception of these spaces and create attractive better spaces and also contributes to the improvement of the visual connection with other parts of the city. [16] In addition, urban voids provide potential in weaving the city together and creating a stronger urban fabric at the city. [11]

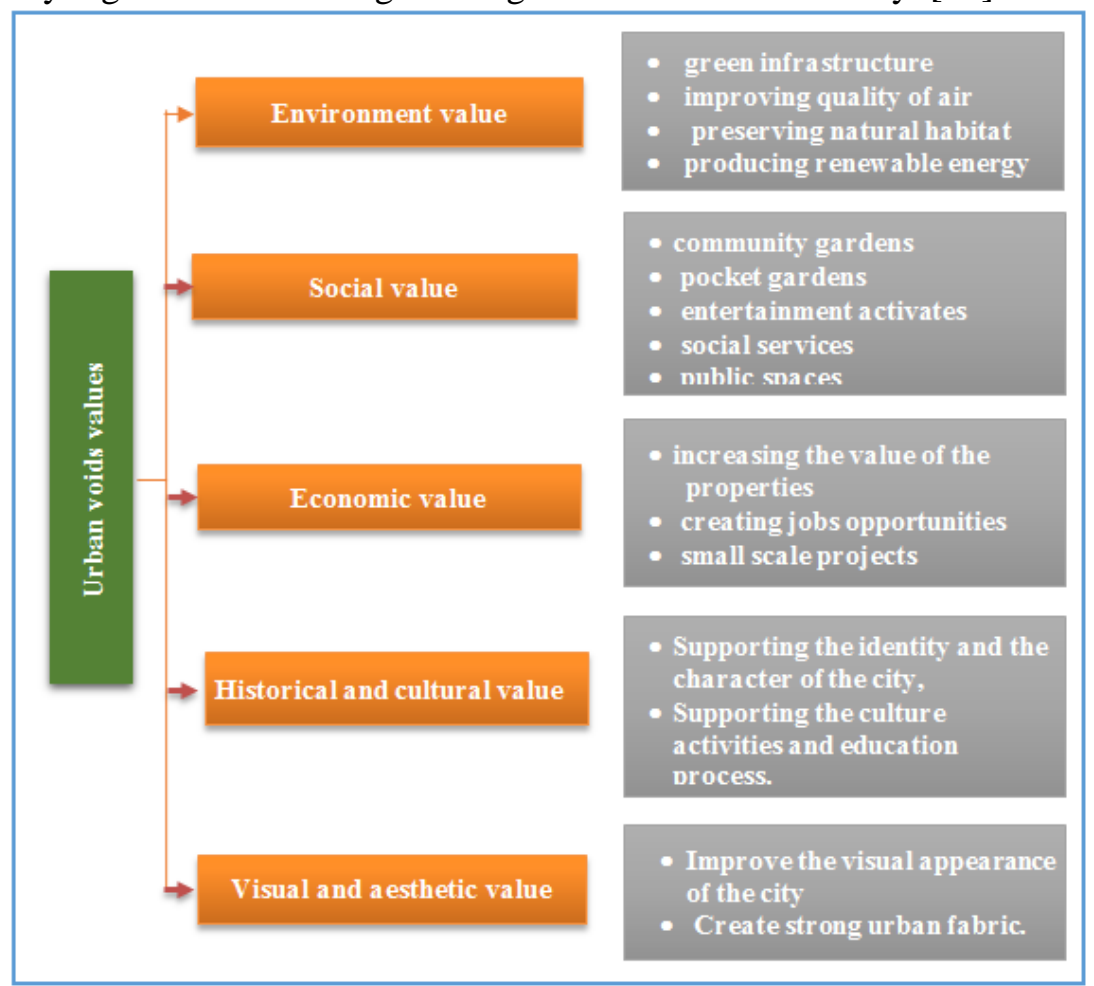

Fig. 1. Urban voids values - Source: authors

\section{International examples}

This part of study represent international examples that has experimented with new ways of dealing with a particular challenges of reuse urban voids as a potential resource for the city development and analysis of these experiments to take advantage of their positives and disadvantages in order to develop a framework for improve the way of development and reuse of urban voids. This part focuses on three examples; Zaragoza- Spain, Cleveland- US and Kwan Tong-Hong Kong.

\subsection{Zaragoza-Spain (this is not a plot)}

Zaragoza city have many problems as insufficiency of public spaces which decrease the urban standard of living. In addition, non-built site affect negatively the aesthetics of the urban landscape, health and living conditions. 
Many surveys and investigations made on the old part of Zaragoza. More than 200 urban voids sites has been registered in the old town, most of which are located in district of (San Pablo) and (La Magdalena) [Firure-2]. [23] The experience of recover urban voids in Spain cities began with civic engagement and collective initiatives that pave the way for the local government to take domestic policies to take advantage of these spaces. In 2009 the city council of Zaragoza draws up program that aim to activate urban voids and clean up plots and neglected sites in the historical center of the town. The name of the program was (this is not a plot) it is a project of cleaning, re-habitation and maintenance the urban voids within the city and the recovery of the same to make them open spaces to neighbors. The project also aims to use dynamic, flexible and temporary ways to extend the open public use area of the city. [19]

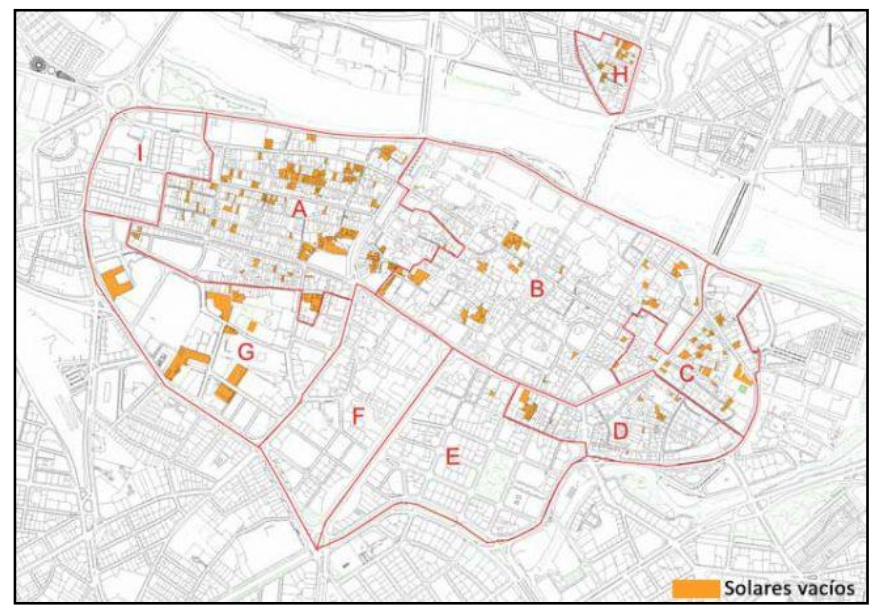

Fig. 2. Urban voids in Zaragoza - Source: (http://www.morethangreen.es)

- Project funded and stages: The project funded from Zaragoza city council, official college of architects of Zaragoza, school of technical Architecture of Zaragoza and Zaragoza school of architecture. The project included several stages; the first stage is presentation the projects for the urban voids recover. Secondly, cleaning and rehabitation of these spaces. And finally, maintain the spaces for public use.

- Project objectives: The objectives of the project was provide public use for urban voids and neglected spaces in city center that provide solutions to the many demands, especially in high density populated and degraded central districts. Also, create some jobs and employment market, for long term development, for people who are unemployed within participatory process which people can offer their experience to the project. The project also provide training and vocational education and promote social and urban innovation through collaboration between many agencies such as (public schools, children organizations, citizen , government agencies) with the support of the Municipal Board of the historic center of Zaragoza and Zaragoza municipal housing society. Through the coordination between local authorities, children organization, urban centers and citizen's, many workshops have been prepared to bring architecture to children which their age from 5-12 to develop their suggestions for the use of urban voids. Many proposals were made by children and citizen through a consistent participatory process. The proposal have been; children play grounds, leisure areas, urban gardens, sport facilities and urban vegetable gardens.[Firure-3] These suggestions provide dynamic public areas in the city and gave a new image of the city. [19-23] 
- Projects Outcomes: The project initiate date 2009 and end date 2011. There are a total of $42000 \mathrm{~m} 2$ of urban voids have been transformed in to public spaces and create new dynamic spaces with participation of about 60 organization. This program has attracted interest from various professional groups, university, public institutions and has earned many awards.

Public -private partnership and land management agreement between private owners and local government to promote and prioritize community partnership.

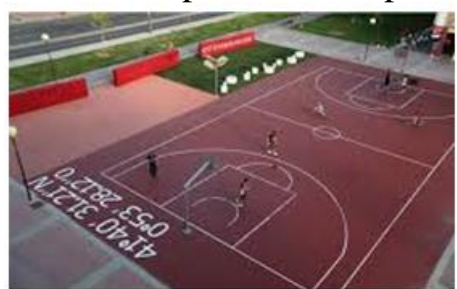

Sport facilities

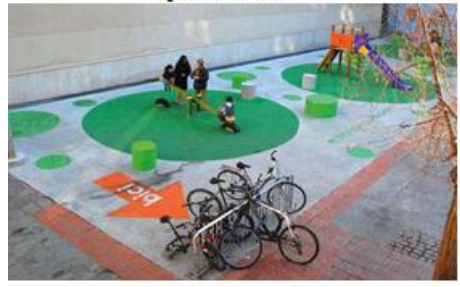

Play ground

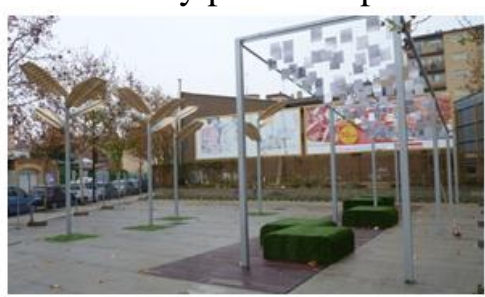

Leisure spaces

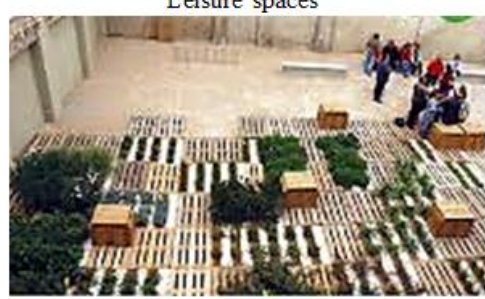

Community gardens

Fig. 3. re-use urban voids in Zaragoza-(this is not a plot) - Source: (Application form for implementation of best practices 2013)

\subsection{Cleveland-US (Re-imagining Cleveland)}

For decade Cleveland, Ohio and another Us cities that called Rust Belt cities faced a lot of problems and crisis .this crisis were represent in loss of population which residence have been leaving the city core because of deindustrialization. In addition, the foreclosure crisis on 2008, this crisis led to create higher level of properties vacancy and abandonment. For example in Cleveland $8 \%$ of lots have vacant structure and additional $18 \%$ of lots are vacant lots [figure- 4]. The amount of vacant land in city center represent a great opportunity to develop the city and the crisis have created the push and potential for the city to re-imagine its future [27]

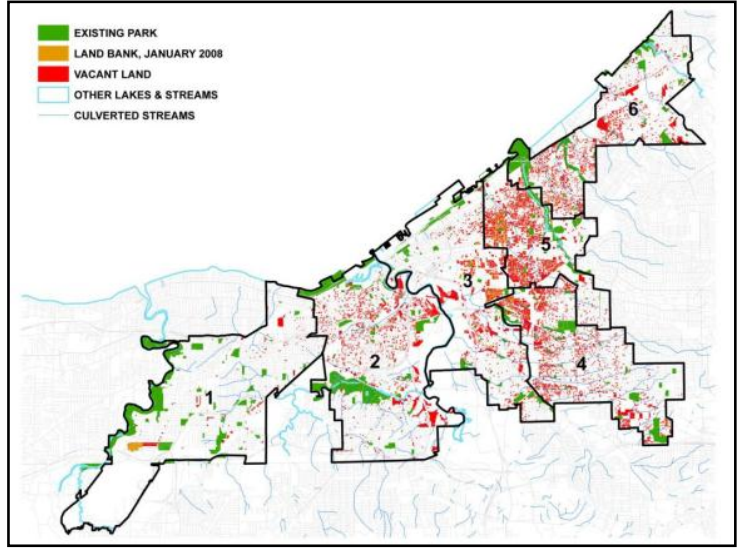

Fig. 4. Cleveland map of vacant land - Source: Reimagining a More Sustainable Cleveland 
- Project objectives: The re-imagining Cleveland vacant land project explored strategies for utilize the vacant land with objectives of making Cleveland a cleaner, healthier, economically and more beautiful. [27] That provides a better quality of life for its residence. The process included working groups of 30 stakeholders from various level of governmental and non-profit organizations, Kent state University, urban design collaborative. The project started in 2006 with informal conversations, the initial report outlining goals, policies, strategies which designed to provide sustainable reuse of vacant land in the city. The strategies outlined in this report were adopted by the Cleveland city planning commission in 2008.

- Project funding and stages: The project consists of three rounds of funding from various sources. Round one (2009) was a comparative application to reuse vacant lots which owned by city land bank this round funded from NPI/NSPI (500000\$). Round two (2011) focused on the reuse of vacant side yard this phase funded from neighborhood stabilization program by (1milliom4). Round three (2014) consisted of larger reuse projects it was funded from the national wells Fargo justice department settlement by $(320000 \$)$.

The first round consists of 52 small grants of residence to reuse vacant lots. Over half of projects were being agriculture community gardens and the rest being recreational green space, pocket gardens and greening on streetscape improvement. One year license agreement was signed to allow resident to use the vacant lots owned by the city land bank for one dollar per year and after the land bank process was updated in 2010 the period increased to 5 years leases for 1 dollar per year. [27]

- Project outcomes: Provision long -term leases of vacant land lots and by giving greater priority to sustainable open spaces uses of vacant land.

Re-imagining Cleveland project working group represents eight big ideas for sustainable and productive reuse of the vacant land. These ideas are guided by the themes of improving community, prosperity and public health such as urban agriculture, storm water management, green spaces expansion, alternative energy, land assembly, contamination remediation and sustainable development pattern. Also, Created comprehensive bikeways and green ways and developed trails in place of abandoned rail line. [Figure- 5] [8]

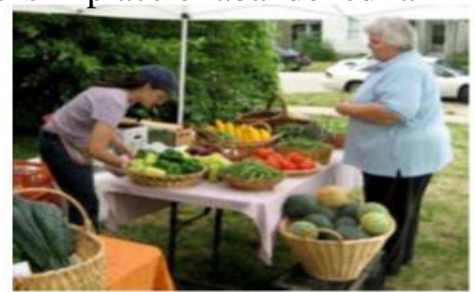

Community markets

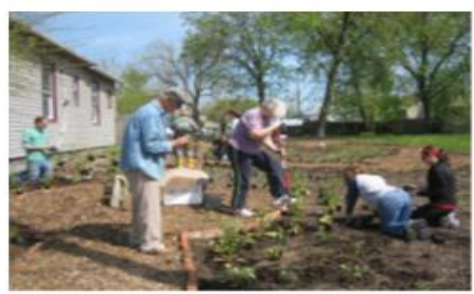

Urban agriculture

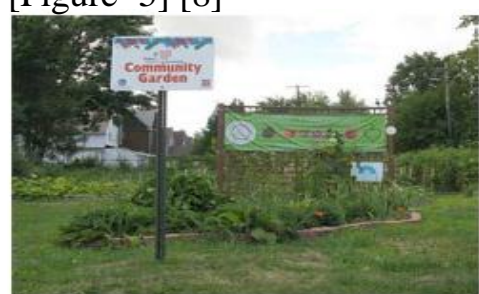

Community garden

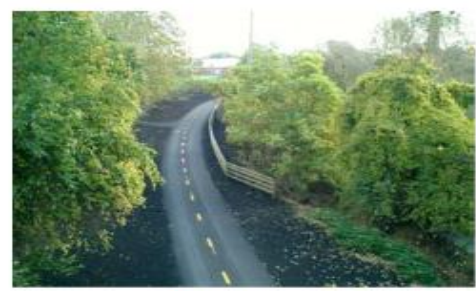

Fig .5. Several ides for re-use vacant land in Re-imagining Cleveland - Source: (Cleveland city planning commission,-2013) 


\subsection{Kwan Tong Bypass-Hong Kong (Fly the flyover)}

Hong Kong city faces problems of rapid urbanization and increasing the population rate that produce many problems in urban development and provide open spaces for people's need. The vacant land under the flyover in the city was often used for temporary purpose such as storage site offices. The fly the fly over operation started by the Energizing Kowloon East Office (EKEO) of the development the Bureau, intends to release the potential of the leftover spaces underneath Kwan Tong Bypass and reuse this spaces for public activities.
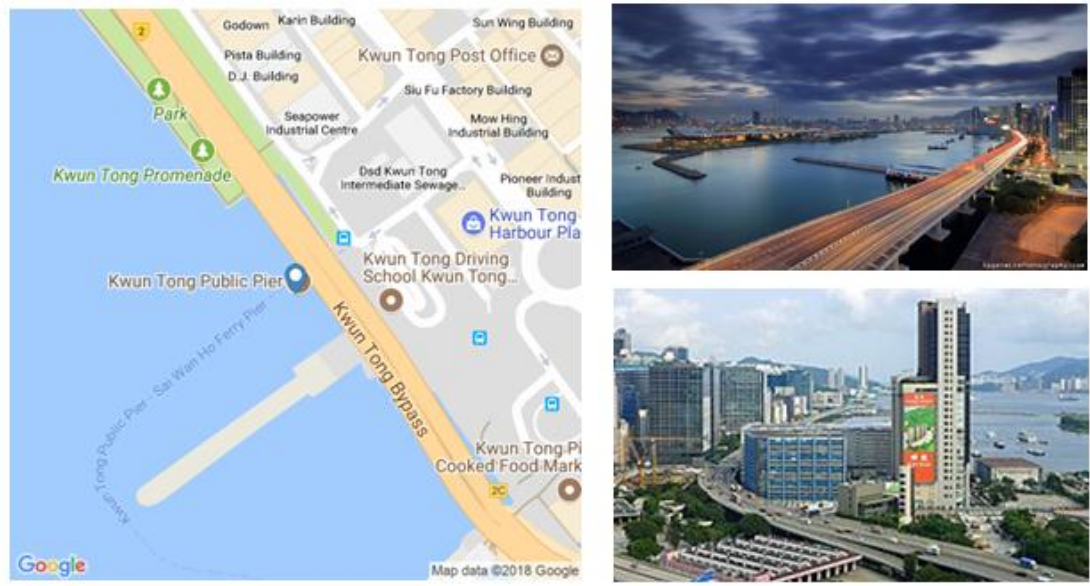

Fig. 6. Kwan Tong Bypass - Source: https://en.wikipedia.org/wiki/Kwun_Tong_Bypass

- Project objectives: The fly the flyover project aim to utilize unused left over spaces underneath Kwun Tong Bypass for creative, art and cultural uses for public enjoyment [Figure-6]. In July 2012, Workshop for artist was held to suggest ideas for better uses for the leftover land. The workshop was supported from architectural services department and its design and construction team. [14-10]

- Project funding and stages: The operation adopted as a partnership approach between EKEO and anon-profit making organization, HKALPS Limited, The project consists of three sites under the Kwan Tong Bypass. The (fly the fly over 01) design and construction work were completed within six months. The operation of this stage was opened in January 2013. Many governmental agencies provided assistance to complete the project in short period of time such as, the Drainage Services Department, Water supplies Department, Transport Department, Electrical and mechanical services Department.

The second and third sites of (fly the fly over 02 and 03 ) were officially opened to the public in September 2017. [10-14]

- Project outcomes: The project opened up to provide creative arts and cultural performances and other activities. An open style design was created as a public space for creative performance, it was constructed by simple design using natural material such as Bamboo and industrial elements such as recycled freight containers were used as the major construction components for the Fly the Flyover sites. Freight containers offer advantages rather than traditional construction materials in order to achieve sustainability. These containers are eco-friendly, costeffectiveness, durability, and flexibility for off-site construction during 
construction. In Kwan Tong many activities were organized such as exhortation, music, dance, outdoor open spaces and sports.

Some basic facilities are provided in the project such as a performance stage, a dressing room, general lighting and toilets. [Figure-7]

The operation brings vibrancy and creates new synergy with the attractive Kwan Tong waterfront.
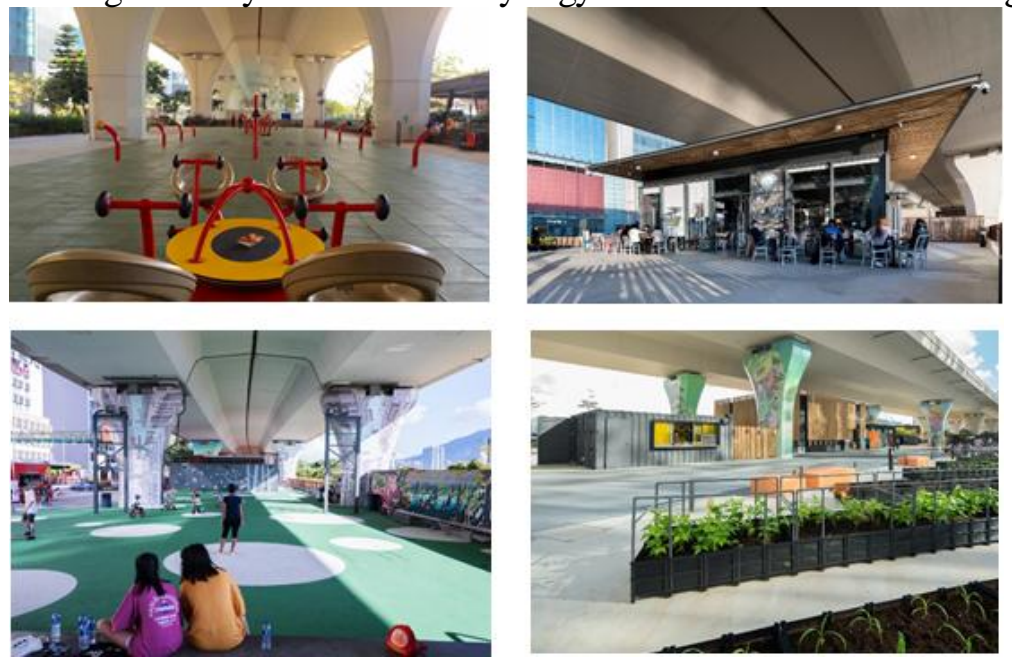

Fig. 7. Several of activates underneath Kwan Tong Bypass - Source: (Fly the Flyover01" opens to public (2013). https://www.info.gov.hk/gia/general/

\section{Urban voids reuse framework}

Through the theoretical study and the analyzing of the previous international projects that experience the reuse of the urban voids, and reviewing the advantages and disadvantages for these experiments. The research concludes a proposed framework to reuse and development the urban voids in the city to improve its functions and to help planners and designers to improve the ways of reusing urban voids to maximize their utilization. This proposed framework contains many stages:

1- Project identification and goal setting: This stage determines the responsible parts and the stakeholders of the process. Through recognize the property of these voids, the users' needs and providing financial resources for redevelopment process by public or private sectors. [15] It is important to define the approach of the reuse development of the urban voids scales; regional and national scale, local - specific place scale. -

2- Inventory and data collection stage: The inventory and data collection considered as the first phase of the regeneration process through utilizing urban voids. Significant progress toward the redevelopment and regeneration of urban voids depends on availability of accurate information and comprehensive database. The Provision of land inventories information is essential for the process and put it in the right track to making better informed decisions. It also can provide information about land-use policies and the economic development and public private partnership. [2]

3 - analyzing stage: The third stage of the reuse development process is analysis the inventory information and identifying how to use the information to determine the high priority for development through identify the land suitability which the process that planning specific criteria based on the existing conditions of the city 
and the objectives of the future development. Land suitability can be defined as the land appropriateness for defined use.

4- Planning and design stage: In this stage it is necessary to establish a strong vision for the redevelopment of urban voids which is identifying the opportunities and using full potential place. And also, set up comprehensive strategies of urban voids development as a part of integrated urban development strategies to achieve best use of urban voids. [1-16] in this stage some consideration should take in to account such as:

- recognize urban voids as integral part of the urban fabric so, design and planning the urban voids should integrate in to the urban context.

- understanding the typology of the urban voids for planners and designers leading to reuse these spaces and maximize the environmental, social, economic, historical and aesthetic benefits gained.

- Holding workshops to increase awareness and knowledge of stakeholders to participate effectively and formulate appropriate decisions and polices on different levels. [1]

- redefine urban voids with new functions by studying the economic, social, historic, culture and environment aspects, in addition study laws and legislations and find design solutions to enhance the spaces components and conditions such as (accessibility, visibility, safety...etc.).

-considering the size of the urban void land in design process into account in the reuse functions, for example small-lots along the road ways may be developed as pocket park, while large lots may be developed as urban agriculture and neighborhoods parks.

-considering the contextual and cultural dimension of the urban voids, and conservation of historic values.

-The redevelopment of urban voids should contribute to sustainable development in the city.

5- Implementation stage: In this stage it is necessary to establish polices to support flexible and sustainable management approach in the development urban voids process to deal with challenged in an intenerated way. [1] In addition, establish a horizontal collaboration of all stakeholders on the all levels, and vertical coordination between the regulatory agencies to ensure coherent development an effectiveness use of resources. It is also necessary to recognize that effective urban voids reused projects should include all stakeholders which need new governance model based on participation of all relevant stakeholders under widely accepted policies. And it is important to empower citizen's participation because people and volunteers are the dynamo of the process and they are the future users of the spaces, and volunteers are the implementation and creative body of the process. [1]

6- post occupancy stage: in this stage it is important to provide tools that used to the assessment of the urban voids redevelopment projects and provide pilot project to regeneration urban voids in order to evaluate the outcomes and obviate the mistakes in another future projects. Also represent evidence to citizens that positive changes can be happen. [1-16]

7- Maintenance stage: Establish maintenance program of different types of urban voids by city government and multiple agencies. And also, providing financial 
resources for the maintenance through funding supplied from multiple resources such as (rate payer fee, taxes, private sectors...etc.).

In this stage it is important to Support the private maintenance of urban voids and community volunteers who maintain sites that are derelict with vegetation

\section{Conclusion}

Urban voids considered a great opportunity and potential to development the city and enhance the quality of life of its residence. It also considered a potential resource due to its value and benefits for urban development program. From the reviewing of literature studies about urban voids the study provide understanding of the meaning of the urban voids and the ways of its formations and also the negative effect of existing urban voids on the city quality of life. The research represents the urban voids as value and explores its values and concludes that the reuse of urban voids can provide environmental value by offering many ecosystem functions such as using urban voids as a green infrastructure, improving quality of air, preserving natural habitat and producing renewable energy. Urban voids can also provide social values by reusing it as a community gardens, pocket gardens, entertainment activates, social services and public spaces for gathering and community interacting. These voids also provide an economic value by reusing it as a small local business which support economic revitalization for example temporary uses, increasing the value of the properties and its surrounding and creating jobs opportunities such as small scale projects. In addition reuse urban voids considering the historic and identity of the city provide historical and cultural value by supporting the identity and the character of the city, supporting the culture activities and education process. In addition re-imagine the urban voids in creative attractive ways improve the visual appearance of the city and create strong urban fabric.

The research also represent international examples that has experience with new ways of dealing with a particular challenges of reuse urban voids as a potential resource for city development and analysis of these examples to take advantage of their positives and disadvantages in order to develop framework for improve the way of development and reuse of urban voids.

The research concludes that the effective re-use of urban voids required:

- Strong vision and comprehensive strategies of urban voids development as a part of integrated urban development strategies

- Public sector should link all groups to each other and emerge new policies to make balance between all parts involved in the process

- Flexible planning system which have some areas to unexpected changes. Design of urban voids can be seen as ongoing process doesn't stop by implementation process.

- achieve long-term benefits by providing an overall plan of the city, showing the location of the urban voids spaces and define appropriate uses of each location.

- supporting temporary uses which play a key role in cities development due to it can adopt needs and capacities to available resources.

- Importance of public- private partnership in the urban voids redevelopment process.

\section{REFERENCES}

[1] Abd Elrahman, A. (2015) Redevelopment Aspects for Brownfields sites in Egypt. Improving Sustainability Concept in Developing Countries, ISCDC, $2-4$

[2] Aleyander, J. et al. (2015), Vacant Land Inventories Part and Parcel to Revitalization a Public Service. Capstone Report. 
Nermeen ali omar, engy hassan saeed, Urban voids as potentioal resources for the city ........

[3] Bellet, C. (2014), Activating urban voids in Spanish cities: from alternative practices to specific public municipal policies. International Geographical Union Regional Conference Changes, Challenges, Responsibility, International Geographical Union - IGU, Krakow, august.

[4] Certeau, M. de. (1988). the practice of everyday life. Berkeley: University of California Press.

[5] Cirelli, C. (2002), Past and Present "Urban Voids" As Resources for the Future. The Case-Study of Catania. 42nd Congress of the European Regional Science Association Dortmund, August 27th - 31th.

[6] Cirik, U. (2005), A Design Problem of Under-Utilized Spaces: The case of Ankara-Old Industrial District. A thesis submitted to the graduate school of natural and applied sciences of Middle East technical university.

[7] City of Philadelphia Redevelopment Authority. City of Philadelphia Redevelopment Authority. 2009: http://www.phila.gov/pra/buyingProperty.html

[8] Cleveland city planning commission, (2013) 8 ideas for vacant land re-use in Cleveland.

[9] Dessouky, N. (2016) Rethinking Cairo's Elevated Urban Highways: Scoping Impacts and Potentials a Thesis Submitted to The Center for Sustainable Development

[10] Fly the Flyover01" opens to public (2013). Retrieved from https://www.info.gov.hk/gia/general/201301/20/P201301200334.htm

[11] Girolamo, F. (2013), Time and Regeneration: Temporary Reuse in Lost Spaces. Planum. the journal of urbanism. N, 27, vol.2. P.67-73.

[12] Goldstein, J.et al. (2001), Urban Vacant Land Redevelopment: Challenges and Progress. Lincoln Institute of Land Policy Working Paper.

[13] Jégou,F. et al. (2016) Refill reuse of vacant spaces as driving Force for Innovation on Local Level, state of the art

[14] Kabir,S. \& Islam,T. (2015) Innovative Use of Space Underneath A Flyover of Dhaka THAAP Journal: Culture, Art \& Architecture of the Marginalized \& the Poor, p.129-138

[15] Kim, G. (2016) the Public Value of Urban Vacant Land: Social Responses and Ecological Value. Sustainability, 8, 486 P.1-19

[16] Kushwah, Ar. \& Rathi, K. (2017), Urban Voids - Reclaiming Urban Space. International journal of Advance Research, Ideas and innovation in technology, vol.3, P196-202.

[17] Lynch, K. (1981). A Theory of Good City Form. Cambridge: MIT Press.

[18] Lynch, K., Wasting away. Sierra club books, 1990.

[19] Midcities, (2013) Application form for implementation of best practices criteria

[20] Najjar, L. \& Ghadban, S. (2015) In-between forgotten spaces in Palestinian cities: the twin cities of Ramallah and Al-Bireh as a case study. Sustainable Development and Planning VII, WIT Transactions on Ecology and the Environment, VO 1 193, P.811-822

[21] Nefs, M. (2006), Unused Urban Space: Conservation or Transformation? Polemics about the Future of Urban Wastelands and Abandoned Buildings. City \& Time 2.

[22] NYC Parks Green Thumb. About: NYC Parks Green Thumb. 2014. Available online: http://www.greenthumbnyc.org/about.html

[23] Rahmann,H \& Jonas,M. (2011), Urban Voids: The Hidden Dimension Of Temporary Vacant Spaces In Rapidly Growing Cities. The State of Australian Cities (SOAC) national conference. 29 November - 2 December

[24] Rahmann,H \& Jonas,M. (2013), Void. Interstitial practices of doubt and reward. Article.

[25] Trancik, R. (1986). Finding Lost Space: Theories of Urban Design. New York: Van Nostrand Reinhold Company Inc.

[26] Tsadik Belete,T. (2010), Development of Urban Vacant Land The case of Addis Ababaalong Ring Road from Bole Square to Megenaga Square. Thesis Master of Science in Degree of Urban Design and Development

[27] Walker, S. (2018) Crisis-Opportunity, Liability-Asset: Governing Vacant Land Reuse in Cleveland, Ohio. A thesis degree of Doctor of Philosophy Department of Geography and Planning University of Toronto.

[28] Wróblewski, W. (2015), Urban Voids as Communication Gaps Envisioning Architecture: Image, Perception and Communication of Heritage [ISBN 978-83-7283-681-6], Lodz University of Technology, 23-26 September 5, pp.466-474. 


\section{الفراغات الحضرية الثاغرة كموارد كامنة لإعادة تنمية المدينة}

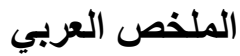

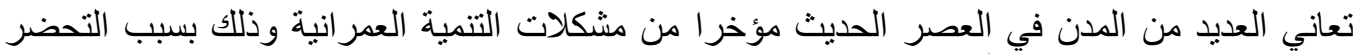

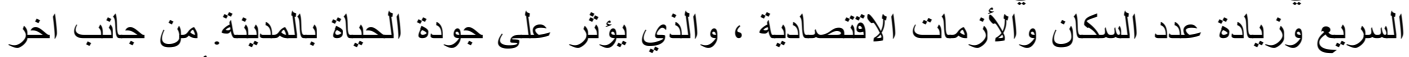

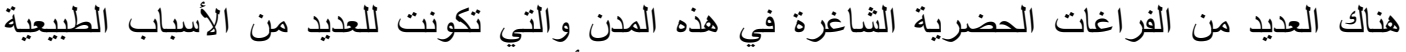

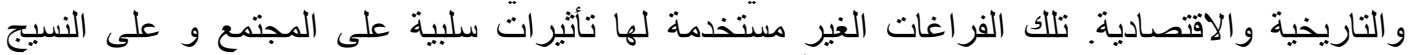

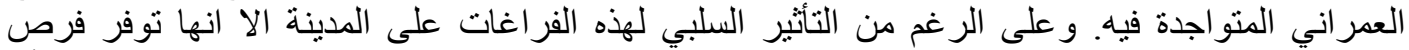

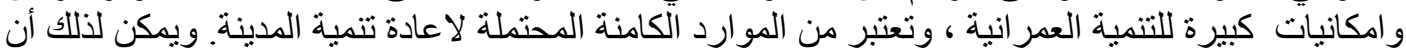

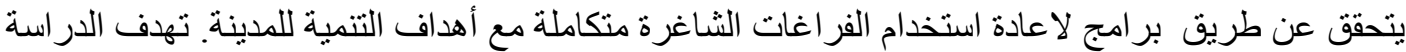

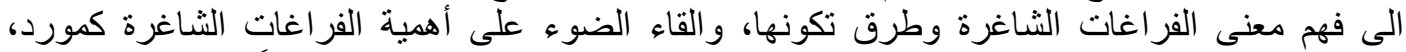

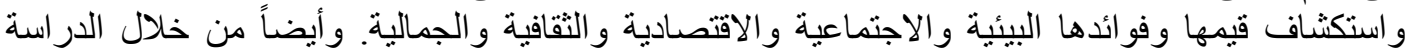

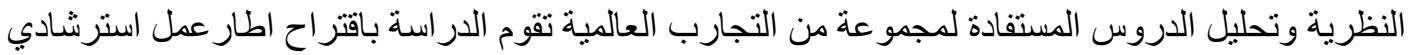

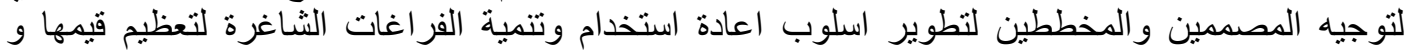

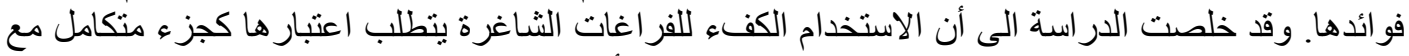
النسيج العمر اني للمدينة من خلال تتسيق التعاون بين جميع الأطر اف المشاركة في عملية التطوير. الكلمات المفتاحية: الفر اغات الثاغرة ـ الموارد الكامنة ــ اعادة الاستخدام 